\title{
Higher attaining but emotionally brittle: Why we need to assess how school marketing policies affect students
}

\author{
Stuart Norris
}

\begin{abstract}
The entrenching of competitive values within the public-market field of secondary education has led to the formation of academically focused institutions whose budgets and reputations are based on gaining large numbers of students who have the best chance of attaining highly in public exams. Although parents have become savvier about their consumer rights, and as regards the use of advertisements that schools produce, the medium and long term impact of the deployment of the majority of marketization tools on students has yet to be assessed. A consequence of this over-marketing process may be that some students prove to be less successful academically after transfer. If the government continues with a policy based on the market model, the impact of marketing tools that schools implement needs to be assessed so that parents can be secure in the knowledge that first and foremost their child is happy and safe at school.
\end{abstract}

\section{Introduction}

The marketization of education was first introduced by the Conservative government of John Major in the early 1990's. At the time, the idea of the use of educational league tables based on exam performance as a comparison tool to inform parental choice was justified by a number of claims. A market-rich environment would encourage schools to become more efficient in adding value to a student's academic achievements. It would better meet parental needs. It would raise standards within school so that sufficient progress would be made by all (Levin, 2003). This academic focus was tempered by collaborative and cooperative polices introduced by the Labour Party in the late 90's(Finn, 2015), but the embedding of foundational competitive values within the public-market field of education remained (Gewirtz, 2002). When, in 2010, David Cameron became prime minister these marketization principles became the foundations on which the Academies Act built. There was also a shift in focus towards a consumer ethos, in that league tables were used not to measure student performance but to indicate school performance. This discursive shift intensified direct competition between schools in the same catchment area, as schools with low student numbers were affected by lowered available budgets whilst at the same time the Education Department's focus on academic achievement meant that schools competed to gain high attaining students so that league table positions might be maintained or improved (Temple et al, 2014).

Within this evolving environment the use of marketing became a priority for schools. Marketing increased the chances of securing the dual aim of gaining high numbers of high attaining students (O'Prey, 2012). Policies that addressed how students moved, or transitioned, from Primary to Secondary phase were re-evaluated. 
Transitional events such as induction days, open evenings and other open-school happenings, were advertised on a larger scale, and aimed at both parents and students. For example within the county of Nottinghamshire the advertising of transitional events in local newspapers increased, from those involving 15 schools in 2009 to those involving 34 schools in 2015 (Nottinghamshire Post). These advertisements often highlighted to parents a school's perceived good qualities, such as a strong record of academic achievement, whilst attempting to avoid mentioning more negative qualities, such as pastoral challenges like bullying. Although this form of advertising is often received and processed sceptically by the majority of parents, who are savvy about the way this sort of marketization tool is used to sell a product, the impact on students' perceptions of school is less well known (Hicks, 2015).

\section{Year 6 open evenings}

One powerful example of a marketization tool with potential negative consequences is the year 6 open evening. According to Morgan (1999) transfer from primary to secondary school faces students with challenges in liaison between schools, continuity of experience, and issues of language and socialisation. This results in transitional anxiety (Riglin et al, 2013), a factor that has been linked with reductions in attainment, and fluctuating rather than stable emotional states. Transition students have been observed to over-estimate the positives and negatives of attending secondary school (Galton et al 2003). What is important to note is that students are often in a very vulnerable state when they attend marketing events such as a year 6 open evening. Although open evenings were instituted historically to ease transitional anxiety, the focus of the senior leadership team on marketing the school so as to attract the highest attaining students often requires that departments or subject-areas only present an illusion of what actually occurs within lessons, and as such oversell themselves (Abrahams, 2007). Abrahams (2007) argues that the use of open evenings give students an unrealistic view of lessons within secondary school. This results in unrealistic expectations, which contribute to a student's overoptimistic perceptions of transfer. When the student arrives at secondary school and finds the reality of lessons disappoints their expectations, their prior perceptions are not met, and this may contribute to a decline in engagement at school. Evidence to support this view includes a well known dip in student attitudes to learning after transition, linked to a sharp decline in levels of attainment at the start of year 7 compared to those secured in year 6 . This can continue until year 9 (Symonds and Galton, 2014).

\section{A step missed}

The above example of the potential effect of marketing on students' emotional wellbeing and attainment is worrying. This effect can be traced back to Michael Gove who, as Secretary of State for Education, introduced and rushed through Parliament a vast array of reforms which were never assessed for their potentially 
negative impact. The accompanying change of ethos, from a conception of education as being for personal development to one in which education is seen as an element in the servicing of economic variables based on the Asian model of 'people economy', (that is, the idea that individuals are the main commodity of a country), was rhetorically justified by the promise of an increase in academic standards and greater social mobility (Bagley, 2006).

The philosophy which holds that academic performance is the main priority of teaching suffers when reality shines its light on countries which have gone through such a process. South Korea has built a population-focused economy supported by a school system which sees students work for 15 hours a day. As such, it has reaped large economic rewards, boasting one of the fastest growing economies over the past 50 years (Scott, 2012). However as a society South Koreans are now realising the long term impact of this enforced work ethic. In that country the highest cause of death among young people under 16 is suicide.

The loss of focus on the whole child to be seen in the Every Child Matters programme (Riglin et al, 2013), characterised by a deformed view which prioritises attainment above all else, may leave a legacy of stress and unhappiness in which students are academically high-attaining but emotionally brittle. The potential for harm to British children due to rushed changes in policy mean that schools could falsely advertise qualities in lessons in year 6 parent evening to students who are already in a vulnerable state. This would suggest that, as a minimum requirement, an impact assessment needs to be completed so that parents can be secure in the knowledge that first and foremost their child is happy and safe at school, and secondly that their child will have the best chance to succeed academically.

\section{Conclusion}

The current educational system based on longer hours and a more rigorous academic focus has produced an increase in attainment. This can often be used to support academisation processes, although the argument is over-simplified in that typically academies are significantly more advantaged in a range of ways than the average secondary school (Machin and Vernoit, 2010). This increased focus on attainment has been seen to be detrimental to the levels of anxiety and stress that a student now faces when transitioning between Primary and Secondary school, and a cause of fluctuating rather than stable emotional states. At the same time, within the emotionally charged moment of school transition, the competitive values of a market oriented schooling process may be causing harm. Although it may be understandable that schools advertise themselves to gain the most high-attaining students, the danger is that schools which find themselves performing less strongly than their competitors in terms of public academic assessment will use marketing 
strategies to over-sell other aspects of the school in order to encourage students to choose that institution. Some parents are able to filter the rhetoric from the reality. But their children, who often accompany them to transition events, may be more vulnerable to this form of persuasion. It is remiss of any institution not to assess its policy in relation to any negative impact that may accrue, especially as regards vulnerable groups. If a balance is not put in place whereby pastoral and academic values are assessed as being equally important when choosing a school, then one result could be students who are high-attaining but emotionally disengaged.

\section{Acknowledgement}

This work is my own. I am grateful to the School of Education in the University of Lincoln for their guidance when appropriate and to my former colleagues in the teaching sector for their input.

Correspondence: snorris@lincoln.ac.uk

\section{References}

Abrahams, I. (2007) An unrealistic image of science. School Science Review, 88: 119-122.

Bagley, C. (2006) School choice and competition: a public-market in education revisited. Oxford Review of Education, 32:3, 347-362.

Bagley, C and Hillyard, S. (2015) School choice in an English village: living, loyalty and leaving. Ethnography and Education, 10:3, 278-292.

Finn.M. (2015) The Gove Legacy: Education in Britain after the coalition. London: Palgrave and Macmillan

Galton, M. Gray, J. and Rudduck, J. (2003) Transfer and transitions in the middle years of schooling (7-14): Continuities and discontinuities in learning. Research Report RR443. London: Department for Education and Skills.

Gewirtz, S. (2002) The managerial school. Post-welfarism and social justice in education. London: Routledge.

Hicks, T. (2015) Inequality, marketisation and the left: Schools policy in England and Sweden. European Journal of Political Research, 54: (2) 326-342 
Levin, B. (2003) Educational policy: commonalities and differences, in: B. Davies \& J. West-Burnham (Eds) Handbook of leadership and management. London: Pearson.

Machin, S and Vernoit, J. (2010) Academy schools: who benefits? Centrepiece Autumn, CEP Policy Analysis.

Morgan, C. (1999) The Process of Transfer from Primary to Secondary in a Bilingual Schooling Context. International Journal of Bilingual Education and Bilingualism, 2: (4) 233-251.

O'Prey, P. (2012) Analysing a decade of change. Patterns and Trends, 363-372

Riglin, L. Fredrickson, N. Shelton, K. and Rice, F. (2013) A longitudinal study of psychological functioning and academic attainment at the transition to secondary school. Journal of Adolescence, 36: 507-517.

Scott, E. (2012) Should industrial development then be regulated by the government, or follow a planned path, or be exposed to foreign trade and investment so that the domestic industries can learn from the industries of the developed world? Development Economics, 34-36

Symonds, J and Galton, M. (2014) Moving to the next school at age 10-14 years: an international review of psychological development at school transition. Review of Education, 2: (1) 1-27

Temple, P. Callender, C. Grove, L. and Kersh, N. (2014) Managing the student experience in a shifting higher education landscape.The Higher Education Academy. 